\title{
A SUBMARINE SONAR STUDY OF ARGTIC PACK ICE
}

\author{
By Elizabeth Williams, Charles Swithinbank, * and G. de Q. Robin \\ (Scott Polar Research Institute, Cambridge, England)
}

\begin{abstract}
A continuous profile of the Arctic Ocean ice canopy from Spitsbergen to the North Pole was made with $48 \mathrm{kHz}$ echo sounders mounted on a nuclear submarine. A semi-automatic digitizer was used to measure coordinates from the records at a frequency of about I ooo points per linear kilometre of track. Methods derived for the reconstruction of subglacial relief from $35 \mathrm{MHz}$ radio-echo sounding records were applied to eliminate part of the distortion due to the $20^{\circ}$ beam width of the sounders. A corrected profile was used to obtain ice drafts at $2 \mathrm{~m}$ intervals. Data were analysed in $10 \mathrm{~km}$ sections and figures were summarized for each degree of latitude. The results include: mean ice draft, percentage of ice less than $0.3 \mathrm{~m}$ draft, and percentage of level ice. Histograms show the level ice drafts which occur most frequently, and these may indicate the ratio of first-year to older ice. The number of ice keels is listed together with their mean draft and draft distribution. Definitions are found to be of overriding importance in the comparison of data from different areas.
\end{abstract}

Résumé. Une étude au "sonar" sous-marin de la banquise Arctique. Un profil continu de la couverture de glace de l'Océan Arctique du Spitsberg au Pôle Nord a été réalisé avec un sondeur à écho de $48 \mathrm{kHz}$ monté sur un sous-marin nucléaire. Un digitaliseur semi-automatique était utilisé pour mesurer les coordonnées à partir des enregistrements à une fréquence d'environ I ooo points par kilomètre linéaire de chemin. Pour la reconstitution du relief sous-glaciaire, les méthodes appliquées dérivaient de celles utilisées pour les sondages par radio-écho à $35 \mathrm{MHz}$ afin d'éliminer en partie la distorsion due à l'ouverture $\left(20^{\circ}\right)$ du cône de dispersion des sondeurs. On a utilisé un profil corrigé pour obtenir des tirants de glace par intervalle de $2 \mathrm{~m}$.

Les données furent analysées par sections de $10 \mathrm{~km}$ et totalisées pour chaque degré de latitude. Les résultats comprennent: le tirant moyen de glace, la proportion de glace de moins de o, $3 \mathrm{~m}$ de tirant et la proportion de glace plane. Des histogrammes montrent les tirants de glaces planes qui sont les plus fréquentes et ceci peut être une indication pour le rapport glace de l'année/glace plus ancienne. Le nombre des glaces chavirées est confronté avec leur tirant moyen et la distribution des tirant. On a conclu que les définitions étaient d'une importance primordiale dans la comparaison des résultats issus de différentes zones.

Zusammenfassung. Untersuchung arktischen Packeises mit Unterwasser-Sonar. Mit einem 48 kHz-Echolot wurde von einem Atom-Unterseeboot aus ein zusammenhängendes Profil der Eisdecke über dem Arktischen Ozean zwischen Spitzbergen und dem Nordpol aufgenommen. Zur Messung von Koordinaten aus den Aufzeichnungen mit einer Dichte von etwa I ooo Punkten pro km Profilspur diente ein halbautomatisches Digitalisiergerät. Unter Anwendung von Methoden, die für die Rekonstruktion subglazialen Reliefs aus $35 \mathrm{MHz}-$ Radar-Echoaufzeichnungen entwickelt waren, wurde die Verzerrung, die durch den Abstrahlwinkel des Lotes von $20^{\circ}$ auftrat, teilweise beseitigt. Aus dem verbesserten Profil wurde der Tiefgang des Eises alle $2 \mathrm{~m}$ abgeleitet. Die Daten wurden in Abschnitten von $10 \mathrm{~km}$ analysiert, die Zahlen für jeden Breitengrad zusammengefasst. Die Ergebnisse enthalten den mittleren Tiefgang des Eises, den Prozentanteil des Eises mit weniger als $0,3 \mathrm{~m}$ Tiefgang und den Prozentanteil ebenen Eises. Die häufigsten Tiefgänge ebenen Eises sind in Histogrammen dargestellt, aus denen das Verhältnis einjährigen zu älterem Eis entnommen werden kann. Die Zahl der Eiskiele, ihr mittlerer Tiefgang und die Verteilung des Tiefgangs erscheinen in Tabellen. Es liessen sich Erklärungen finden, die von ausschlaggebender Bedeutung für den Vergleich von Daten aus verschiedenen Gebieten sind.

\section{INTRODUCTION}

A continuous profile of the Arctic Ocean ice canopy was made with $48 \mathrm{kHZ}$ echo sounders mounted on a nuclear submarine. A preliminary analysis by one of us (Swithinbank, I972) discussed the measuring system, the observed ice characteristics, and some broad conclusions drawn from the study. We now report on a statistical analysis that throws light on the true mean thickness, the ridging history, the total mass of ice, and the stability of the ice cover. The data were obtained by H.M.S. Dreadnought on 4-5 March $197 \mathrm{I}$ in lat. $85^{-} 90^{\circ} \mathrm{N}$., long. $6-7^{\circ} \mathrm{E}$.

* British Antarctic Survey from I October 1971. 


\section{Data reduction}

The earlier paper described the method used to enter a sea-level base line on the records. The highest openings in the ice were joined by a straight line on the assumption that they represented patches of open water. In our analysis we have accepted this base line and have related all drafts to it. However, in surfacing six times through skylights and polynyas, it was noted by direct observations that the highest openings in the pack ice were covered by new ice, nilas, or young ice varying in thickness from $5 \mathrm{~cm}$ up to $30 \mathrm{~cm}$. A mean line drawn through a plot of these ice thicknesses against latitude has been used to determine approximate corrections to the mean drafts for use in Tables I to III. In the diagrams, true ice drafts may be up to $30 \mathrm{~cm}$ greater than is shown.

A semi-automatic pencil follower measuring to $0.1 \mathrm{~mm}$ was used to digitize the profiles at a frequency representing one or more points per linear metre of the submarine's track. Sections in which the speed of the submarine was varying were not used. Where there was an instrument malfunction or where an ice keel went off scale from the principal recorder (reading to $25 \mathrm{~m}$ draft) an independent recorder reading to a depth of $35 \mathrm{~m}$ was used. The submarine's speed was averaged over 30 min periods from to min time marks shown on large scale automatic track plots. The speed of the recording paper was averaged over lengths representing $100 \mathrm{~km}$ of track on the basis of similar io min time marks. Computer analysis of the digitized records yielded measured values of ice draft at each $2 \mathrm{~m}$ interval along the track.

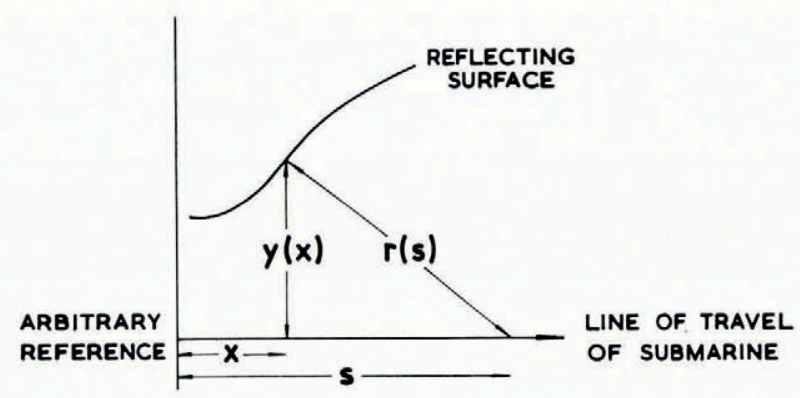

Fig. I. Relationship between real-space coordinates $(x, y)$ of a reflecting point on an arbitrary surface and echo profile coordinates $(s, r)$.

The two-dimensional transformation derived by Harrison (1970, p. i io6) for the reconstruction of subglacial relief from $35 \mathrm{MHz}$ airborne radio-echo sounding records was used to remove part of the distortion resulting from the nominal $20^{\circ}$ beam of the sounder. Using Harrison's notation (Fig. I) we have

$$
\begin{aligned}
& x=s-r \frac{\mathrm{d} r}{\mathrm{~d} s}, \\
& y=r\left[\mathrm{I}-\left(\frac{\mathrm{d} r}{\mathrm{~d} s}\right)^{2}\right]^{\frac{1}{2}},
\end{aligned}
$$

where $r$ and $s$ are measured and $x$ and $y$ are the derived horizontal and vertical distances. Given an uneven reflecting surface, the airborne sounder produced overlapping hyperbolic echoes (Fig. 2a), whereas the very dense nature of the submarine sounder trace obscured all but the first returned signals from any reflecting surface within the cone of reception. The deconvoluted ice profile as seen from the submarine (Fig. 2b) left gaps in the record representing the obscured troughs between ice keels. The best estimate of draft at these 
points was taken to be the minimum apparent draft on the record. This system of deconvolution was satisfactory for slopes up to $8^{\circ}$, just under half the nominal beam width. With greater slopes, the calculations produced a greatly distorted profile that was obviously unreal. In order to take account of the limited beam width of the $48 \mathrm{kHz}$ sounder, we assumed that no energy was radiated outside the main lobe of the beam, and that energy was returned by oblique scattering from a rough surface rather than normal reflection as indicated in Figure $\mathbf{I}$.
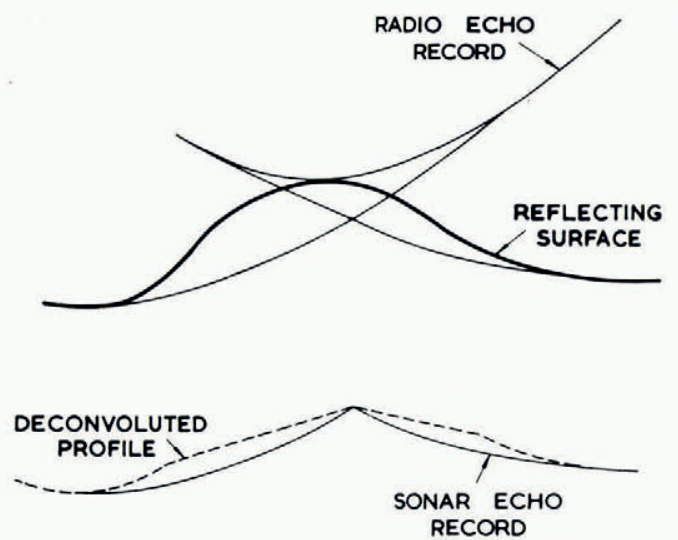

Fig. 2. (a) Hyperbolic echoes on airborne radio-echo sounding record. (b) Gaps in submarine sonar record after deconvolution.

By trial and error it was found that the smoothest overall profile was produced by deconvoluting bottom slopes $<8^{\circ}$, and for greater slopes data points were shifted through $8^{\circ}$ in a direction towards the centre of each ice keel. In other words, we assume that the first scattered return from a steeply sloping surface was received when it first intersected our beam, which had an effective half width of $8^{\circ}$ rather than its nominal value of $10^{\circ}$. Figure 3 compares a section of the corrected profile with the apparent profile given by the echo trace. The net effect of our treatment has been to make the figures for overall mean ice draft about $8 \%$ smaller than those given by the uncorrected profile. If it were possible to develop a satisfactory method of deconvolution in three dimensions, we would expect a further reduction in the overall mean ice draft. If the ridges were of random orientation, we would expect the further reduction to be of similar magnitude. Such corrections do not apply to our discussions of level ice, since no deconvolution was necessary.

SECTION 1715 .

KILOMETRES

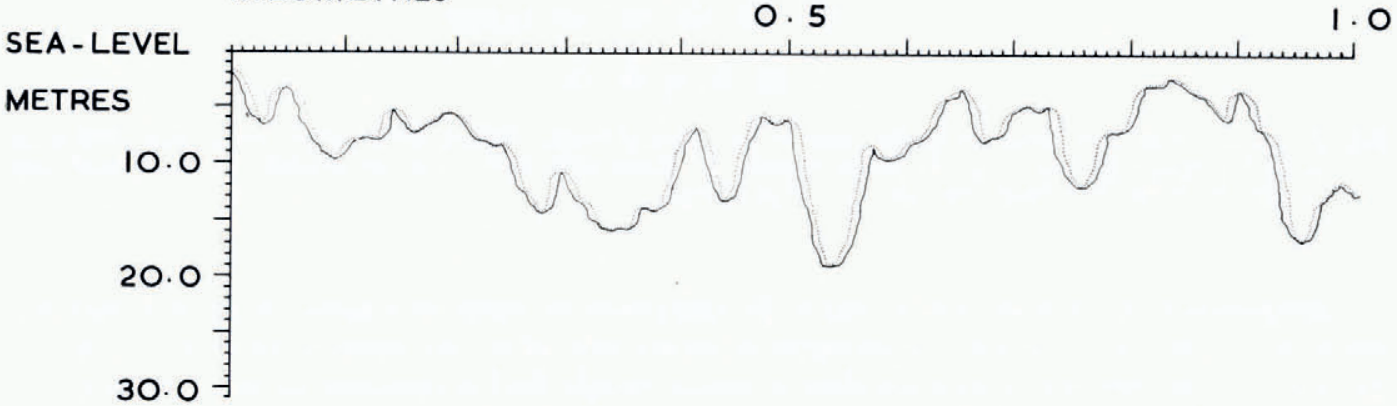

Fig. 3. Tracing of computer product showing original echo profile (full drawn) and corrected profile (dotted). 


\section{Definitions}

For the purposes of this paper we have assigned special meanings to the following terms:

Mean ice draft is the mean of all measured drafts including those of ice keels and open water (entered as zero draft).

Level ice. An ice draft measurement is said to describe level ice if the drafts $4 \mathrm{~m}$ horizontally on either side of it differ by $<20 \mathrm{~cm}$, implying an ice bottom slope of less than I in 40 . Various criteria were tried (Fig. 4); this definition eliminated most of the deep draft values while being least affected by small-scale roughness.

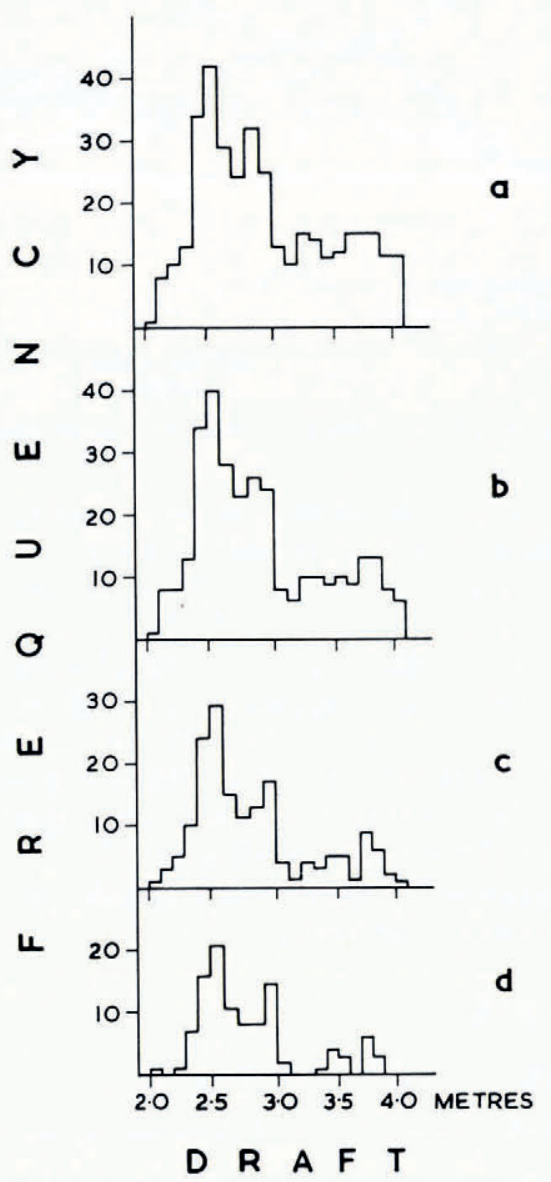

Fig. 4. Histograms of draft frequency for the same $10 \mathrm{~km}$ section of track. Different bottom-slope criteria were tried in an attempt to define "level ice". (a) No points rejected. (b) Points with slope $\geqslant I$ in Io rejected. (c) Points with slope $\geqslant I$ in 20 rejected. (d) Points with slope $\geqslant I$ in 40 rejected.

Independent keel. An ice keel is said to be independent when its maximum draft is not less than twice that of the shallowest troughs on either side of it. Ice keels with draft $<5 \mathrm{~m}$ are excluded. This definition ensures that a broad rough keel is counted as one independent keel rather than as several (Fig. 5). 
SUBMARINE SONAR STUDY OF PACK IGE

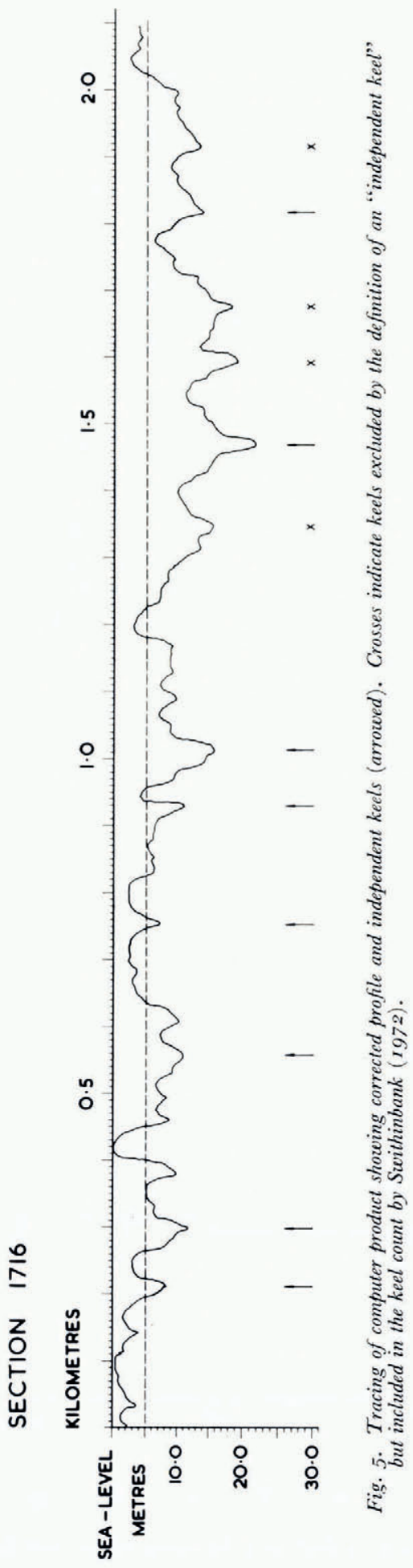




\section{Results}

The corrected profile was analysed in $10 \mathrm{~km}$ sections and summarized for each degree of latitude. Mean ice draft was determined for $\mathrm{I} \mathrm{km}$ and $\mathrm{I}^{\circ}$ sections (Fig. 6) to show the wide scatter of values and also for $10 \mathrm{~km}$ and $\mathrm{I}^{\circ}$ sections (Fig. 7). The $\mathrm{I} \mathrm{km}$ means range from $0.0 \mathrm{~m}$ to $12.1 \mathrm{~m}$, the $10 \mathrm{~km}$ means from $2.7 \mathrm{~m}$ to $6.6 \mathrm{~m}$. Figure 8 shows the proportions of the track covered by ice $<30 \mathrm{~cm}$ draft, level ice, and ridged ice, ridged ice being interpreted as everything other than level ice having a draft $>30 \mathrm{~cm}$. The largest openings occurred in lat. $87^{\circ} \mathrm{N}$., where as much as $21.5 \%$ of one $10 \mathrm{~km}$ section was evidently taken by new ice, nilas, or young ice. There were substantially more openings south of lat. $87^{\circ} \mathrm{N}$. than north of this latitude. One of the most revealing products analyses the draft distribution of level ice in different latitudes (Fig. 9). We do not consider that any significance should be attached to steps representing changes in frequency of $<0.2 \%$, since these could be caused by a single ice floe, but there is no doubt that the general shape of the histograms is significant. We interpret the single peak centred around a draft of $2.5 \mathrm{~m}$ north of lat. $88^{\circ} \mathrm{N}$. as showing the preponderance of old ice in these latitudes. The lat. $87^{\circ}-88^{\circ} \mathrm{N}$. region evidently represents a transition zone, since within it are found the widest variations between $10 \mathrm{~km}$ sections (Fig. 8) with respect to ridged ice (from $51 \%$ to $87 \%$ ) and also with respect to level ice (from $13 \%$ to $49 \%$ ). Moreover around lat. $87^{\circ} \mathrm{N}$. the first large areas of thin ice (up to $22 \%$ ) are found. South of lat. $87^{\circ} \mathrm{N}$. we note the progressive development of three peaks in Figure 9 which probably describe old ice (centred around $2.5 \mathrm{~m}$ ), first-year ice (centred around $\mathrm{I} .5 \mathrm{~m}$ ), and ice formed during the last few weeks ( $<0.4 \mathrm{~m}$ draft). Figure io shows the frequency distribution of ice draft measurements near the North Pole. The reason for the significant number of level ice drafts at depths approaching $10 \mathrm{~m}$ lies with our definition of level ice. Provided that bottom slope criteria were satisfied, the programme described any flat peak of even a deep ice keel as level ice. The break in slope at around $3 \mathrm{~m}$ in the level-ice curve

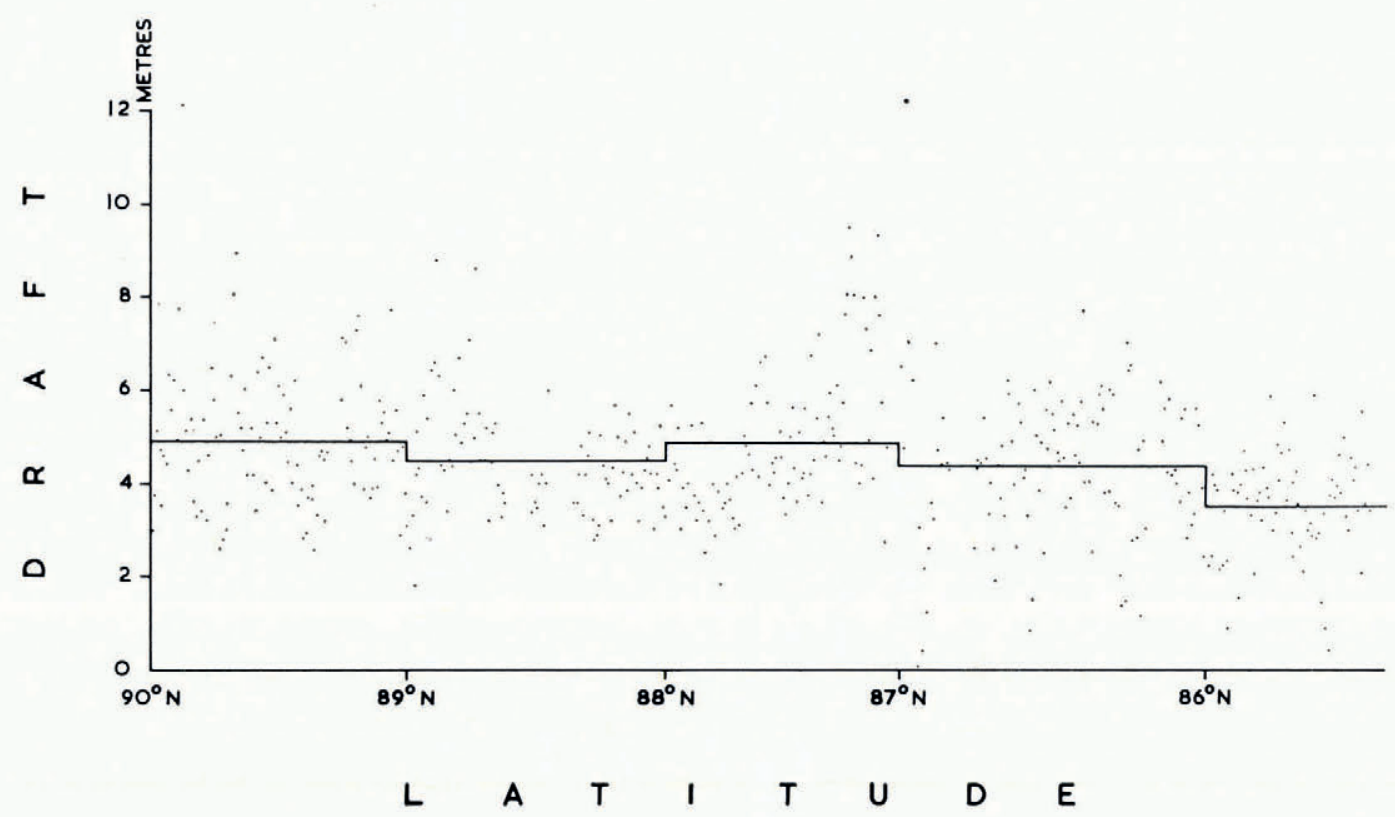

Fig. 6. Mean ice draft for $\mathrm{I} \mathrm{km}$ sections and for each degree of latitude. 


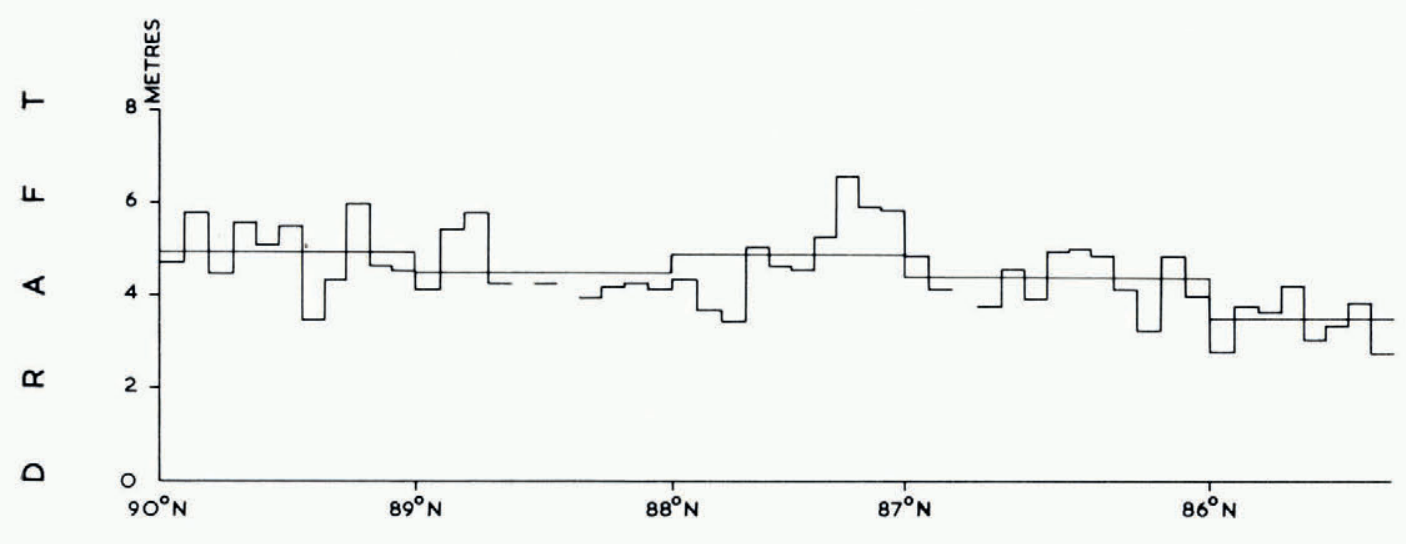

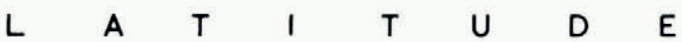

Fig. 7. Mean ice draft for $10 \mathrm{~km}$ sections and for each degree of latitude. Gaps indicate sections with insufficient data.

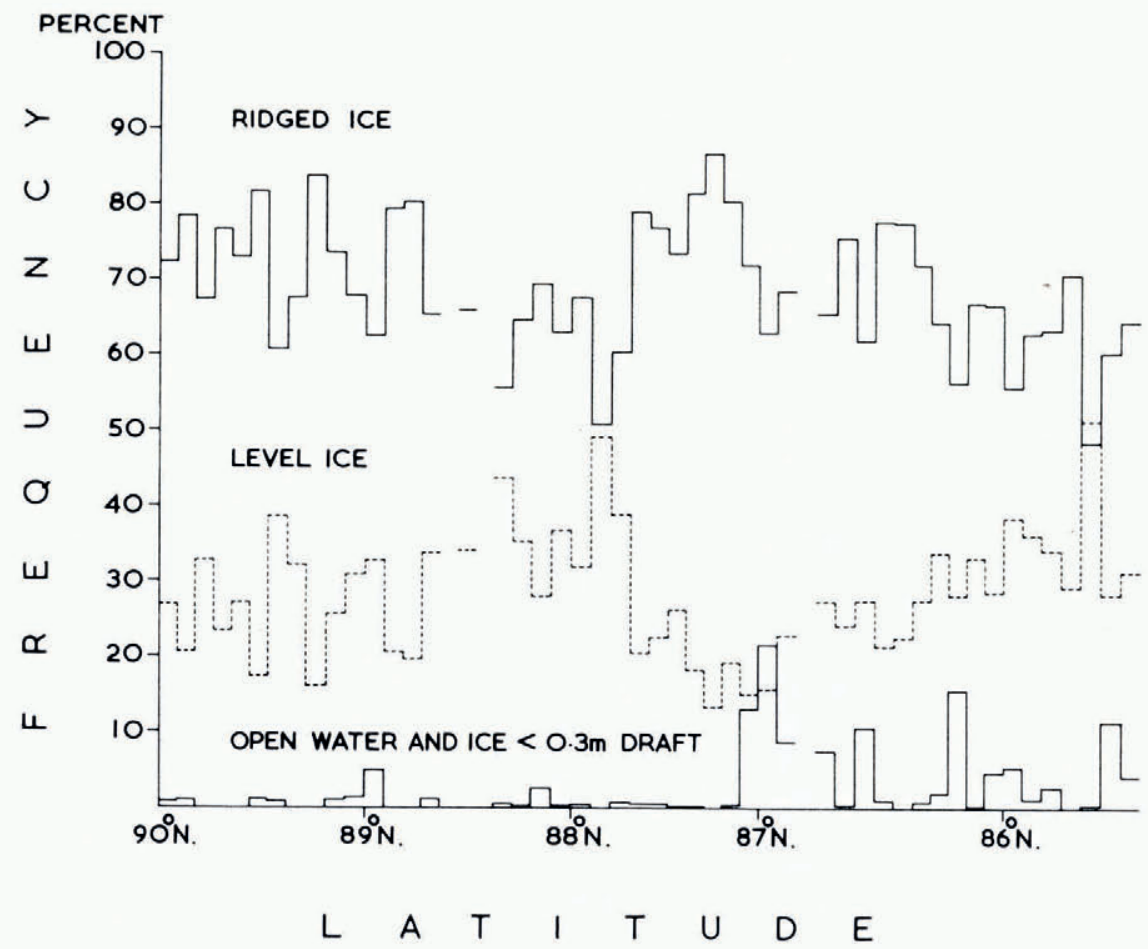

Fig. 8. Percentage of ridged ice, level ice, and thin ice in each $10 \mathrm{~km}$ section. 


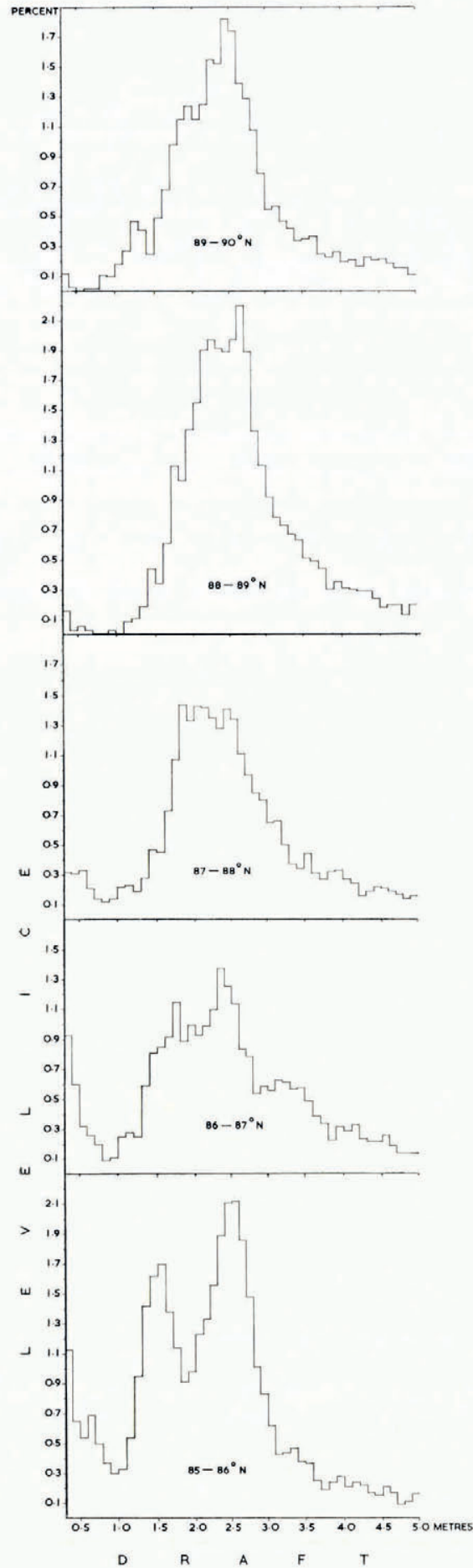

Fig. 9. Histograms of level-ice draft for each degree of latitude. 


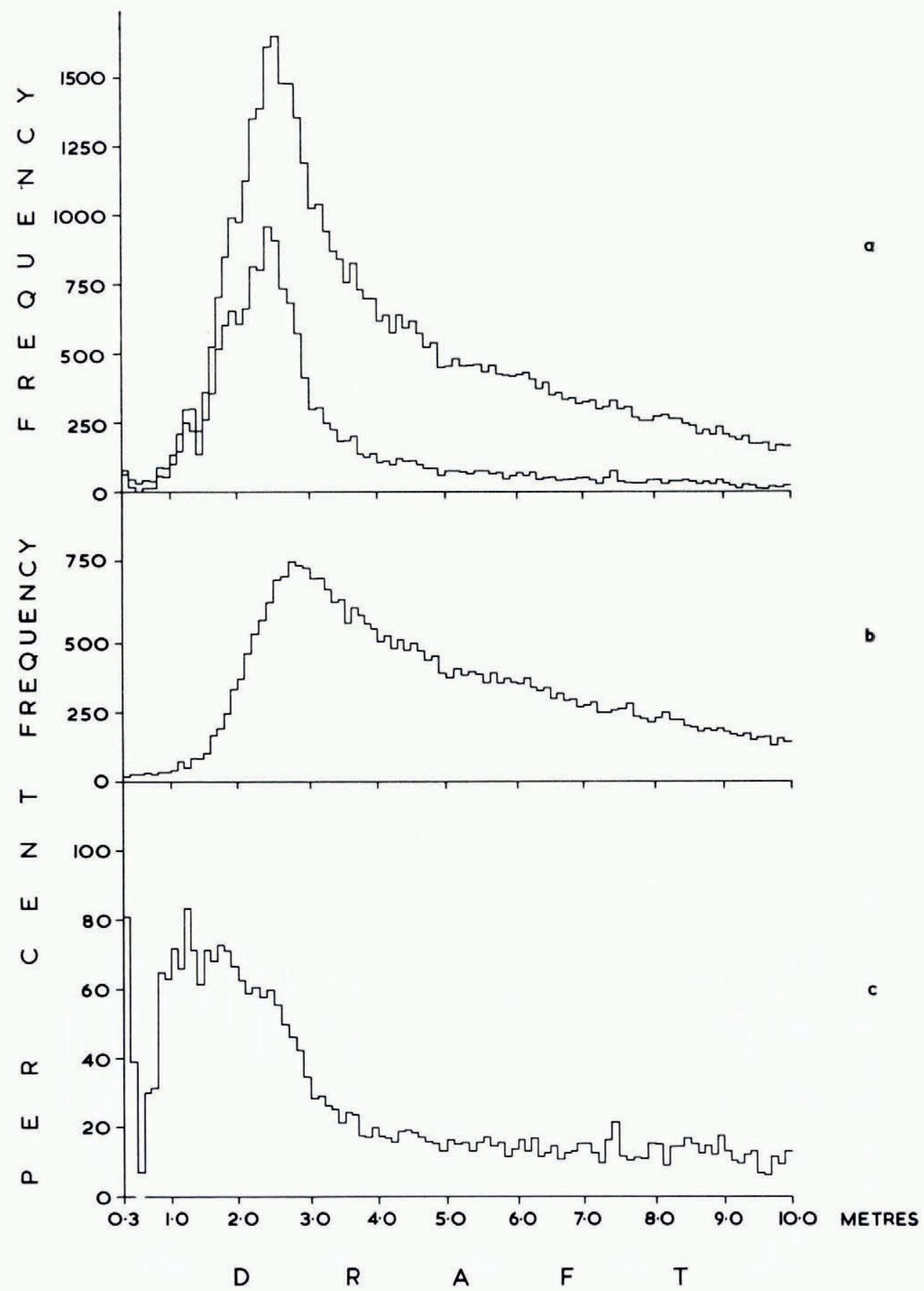

Fig. 1o. Histograms of ice draft in lat. $89-90^{\circ} \mathcal{N}$. (a) All ice (upper curve) and level ice (lower curve). (b) Ridged ice. (c) Level ice as a percentage of all ice. 
(Fig. IOc) evidently indicates the upper limit of undeformed level ice. Table I gives the mean draft of the level ice described in Figure 9 together with a correction for the estimated mean draft of young ice.

TAble I. Mean dRaft of Level ICE Between $0.3 \mathrm{~m}$ And $5.0 \mathrm{~m}$

$\begin{gathered}\text { Latitude } \\ { }^{\circ} \mathrm{N} .\end{gathered}$
$89-90$
$88-89$
$87-88$
$87-88$
$86-87$
$85-86$

Apparent draft
$\mathrm{m}$
2.54
2.65
2.46
2.38
2.16

$\begin{array}{cc}\begin{array}{c}\text { Correction for } \\ \text { young ice } \\ \mathrm{m}\end{array} & \begin{array}{c}\text { Total } \\ \mathrm{m}\end{array} \\ \text { O.19 } & 2.73 \\ \text { O.1 } 7 & 2.82 \\ \text { O.I5 } & 2.6 \mathrm{1} \\ \text { O.13 } & 2.5 \mathrm{I} \\ \text { O.1 I } & 2.27\end{array}$

While the figures north of lat. $87^{\circ} \mathrm{N}$. probably refer to old level ice only, south of $87^{\circ} \mathrm{N}$. the figures probably describe a mean covering old, first-year, and younger ice. Figure I I shows the very wide variations from place to place in the number and mean draft of independent ice keels. Hibler and others (1972, p. 5968), who analysed comparable data from a winter voyage of U.S.S. Sargo, suggest that the statistical properties of ice keels along a given

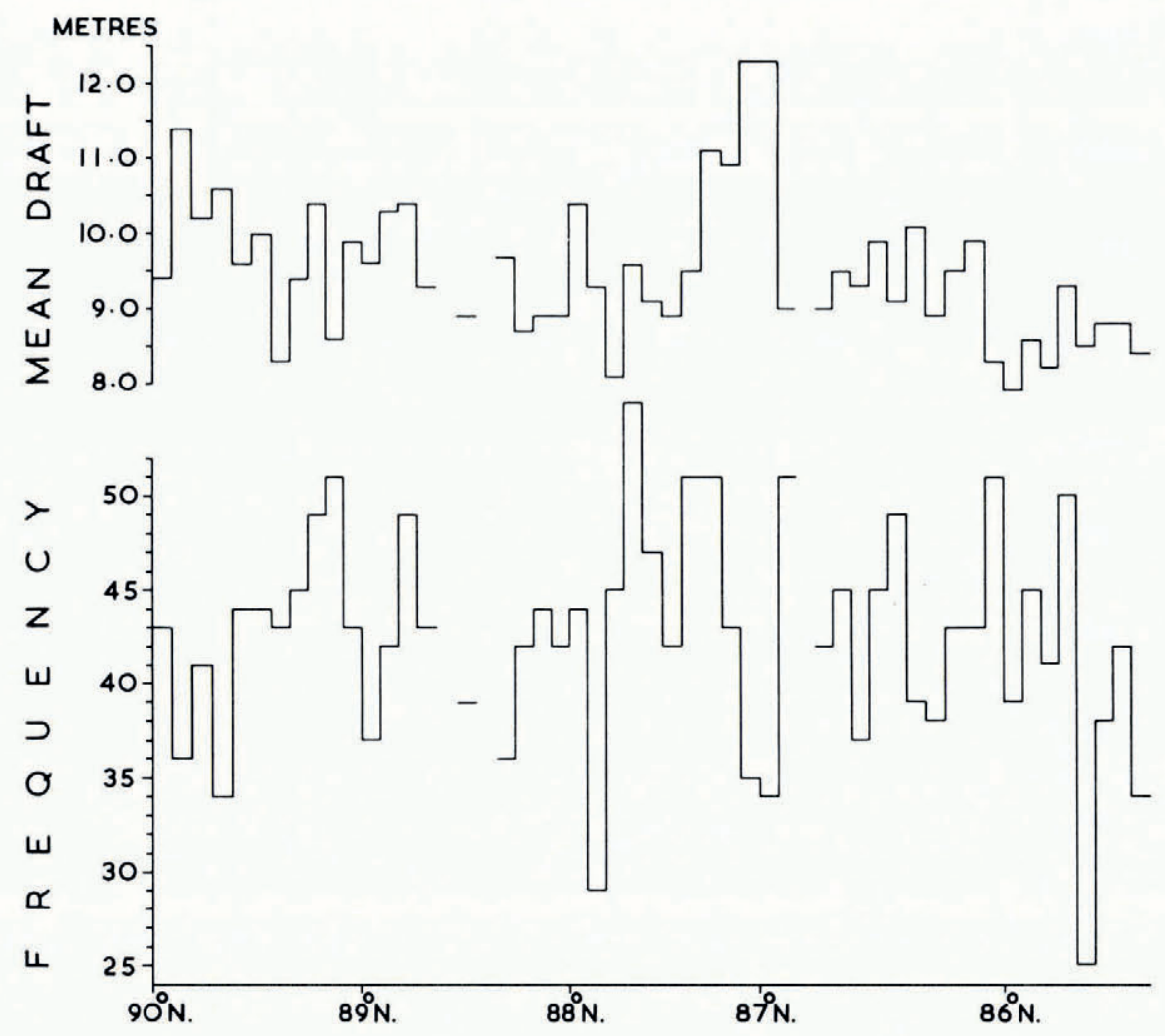

L $\quad \begin{array}{lllllll}\text { A } & \text { T } & \text { I } & \text { T } & \text { U } & \text { D } & \text { E }\end{array}$

Fig. II. Mean draft and frequency of independent keels for each $10 \mathrm{~km}$ section. 
linear track can be characterized by the mean draft and mean frequency of ice keels. In the central Arctic basin over a track length of about $\mathrm{r} 000 \mathrm{~km}$ they found a mean keel draft of $9.6 \pm 0.6 \mathrm{~m}$ and mean frequency of $4.3 \pm \mathrm{r} .0 \mathrm{keels} / \mathrm{km}$. Remarkably, our data (Table II) yield almost identical results: mean keel draft $9.6 \pm$ r.o $\mathrm{m}$ and mean frequency $4.2 \pm 0.6$ keels $/ \mathrm{km}$.

TABle II. MEAN DRAFT AND FREQUENCY OF INDEPENDENT ICE KEels

\begin{tabular}{|c|c|c|c|c|}
\hline $\begin{array}{l}\text { Latitude } \\
{ }^{\circ} \mathrm{N} .\end{array}$ & $\begin{array}{c}\text { Apparent draft } \\
\mathrm{m}\end{array}$ & $\begin{array}{c}\text { Correction for } \\
\text { young ice } \\
\mathrm{m}\end{array}$ & $\begin{array}{c}\text { Mean draft } \\
\mathrm{m}\end{array}$ & $\begin{array}{l}\text { Frequency } \\
\text { keels/km }\end{array}$ \\
\hline $89-90$ & $9 \cdot 76$ & o. 19 & 9.95 & $4 \cdot 3$ \\
\hline $88-89$ & $9 \cdot 43$ & 0.17 & $9 \cdot 60$ & 4. I \\
\hline $87-88$ & $9.8 \mathrm{I}$ & 0.15 & $9 \cdot 96$ & $4 \cdot 4$ \\
\hline $86-87$ & 9.50 & o.1 3 & 9.63 & $4 \cdot 3$ \\
\hline $85-86$ & $8.6 \mathrm{I}$ & O.I I & 8.72 & 3.9 \\
\hline $85-90$ & & & $9 \cdot 57$ & 4.2 \\
\hline
\end{tabular}

However it is evident from Figure i I that there are large differences between the values for neighbouring $10 \mathrm{~km}$ sections. We conclude that to describe average conditions satisfactorily one must average over track sections greater than $10 \mathrm{~km}$ in length. The same authors found a statistically significant linear correlation between the mean frequency of ice keels and their mean draft. Consequently they proposed using the mean frequency to predict the mean draft, or alternatively using the mean draft to predict the mean frequency. Our data do not support such a correlation. Indeed we find the deepest values of mean draft in an

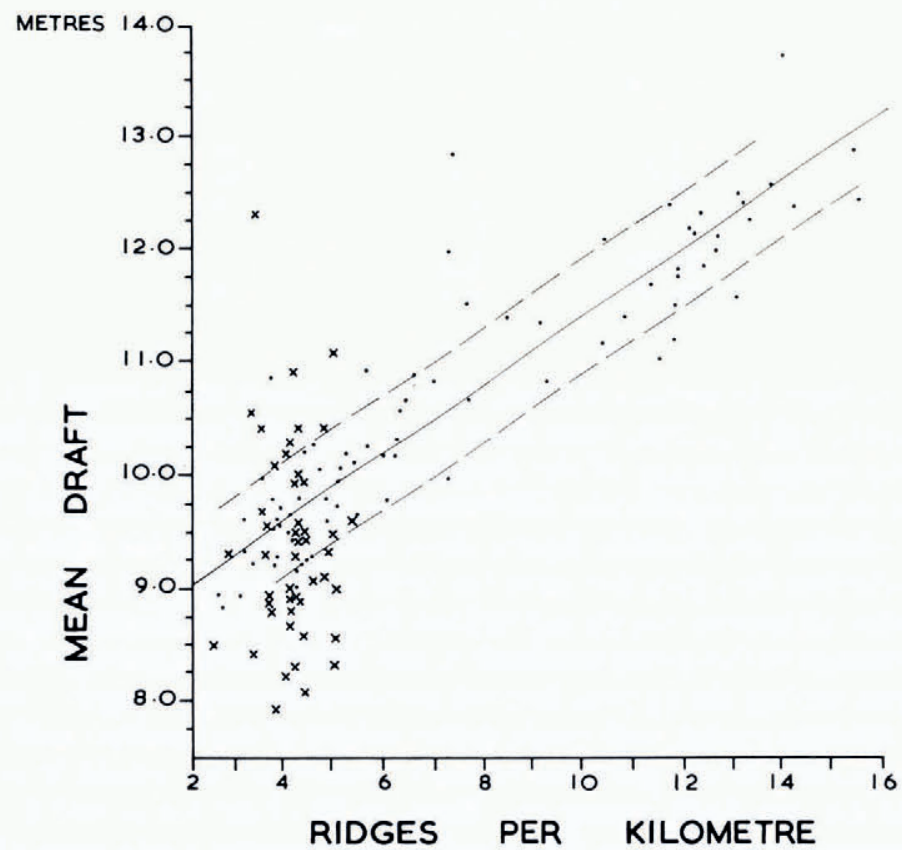

Fig. I2. Mean ice-keel draft correlated with number of $i$ ce keels per kilometre. Dreadnought data (crosses) refer to independent keels $>5 \mathrm{~m}$ draft averaged over $10 \mathrm{~km}$ sections. Sargo data refer to ice keels $>6 \mathrm{~m}$ draft averaged nver $22-33 \mathrm{~km}$ sections. Linear regression line (full drawn) and standard error (dashed lines) for Sargo data. Modified from Hibler and others (1972). 
area with a low frequency of ice keels as we define them (lat. $87^{\circ} \mathrm{N}$. in Fig. II). This can be seen in Figure 12 where both Dreadnought and Sargo data are shown. The former refer to Io $\mathrm{km}$ track sections whereas the Sargo data refer to $30 \mathrm{~km}$ sections. This leads to a greater spread of Dreadnought data, but does not explain why we find no correlation between mean draft and mean frequency.

The cause of this difference probably comes from our definition of an independent keel. This definition considerably reduces the number of keels in comparison with earlier counts (Fig. 5) which are probably derived in a similar manner to counts on the Sargo data. Possibly the Sargo data give an ice keel count that is approximately proportional to the total amount of deformed ice, and it would be reasonable to expect the mean draft of ice keels to be proportional to the volume of deformed ice. Studies of the upper surface by Hibler and others (1974) show a correlation between ridge frequency (definition?) and volume of deformed ice estimated from laser data. While this appears to explain the difference between the two sets of results, it must be remembered that the Sargo data cover both off-shore provinces as well as the central Arctic basin, whereas ours cover the central Arctic basin only; and for this area Hibler and others (1972) report a weaker correlation in any case.

There is no single definition of a ridge or an ice keel that will be satisfactory for all purposes. For someone driving a ship through polar pack ice, we believe our definition is the more useful; but as an indication of the mean draft of ice keels and of the amount of deformed ice it is less useful. Furthermore, the inability of the sonar beam completely to resolve high points between ice keels means that one cannot apply our definition objectively in all cases. However, this limitation applies also to other definitions such as that used by Swithinbank, where poor resolution might have an even greater effect.

\begin{tabular}{|c|c|c|}
\hline $\begin{array}{l}\text { Latitude } \\
{ }^{\circ} \mathrm{N} \text {. }\end{array}$ & $\underset{\mathrm{m}}{\text { August }} 195^{8}$ & $\underset{\mathrm{m}}{\text { March } 197 I}$ \\
\hline $89-90$ & 5.06 & $\begin{array}{l}5 \cdot 13 \\
466\end{array}$ \\
\hline $\begin{array}{l}88-89 \\
87-88\end{array}$ & $\begin{array}{l}5.82 \\
5 \cdot 5^{2}\end{array}$ & $\begin{array}{l}4.66 \\
5.04\end{array}$ \\
\hline $86-87$ & 6.03 & $4.5^{2}$ \\
\hline $85-86$ & $5 \cdot 35$ & $3.6 \mathrm{I}$ \\
\hline $85-90$ & $5 \cdot 56$ & 4.29 \\
\hline
\end{tabular}

Table III compares the mean ice drafts from the trans-polar voyage of U.S.S. Nautilus in August 1958 (Lyon, I961, p. 670) with those from H.M.S. Dreadnought in March 1971. The Nautilus track lay within $150 \mathrm{~km}$ of the Dreadnought track and we would not expect such a small separation to lead to significant differences in the mean ice thickness. Furthermore we are not certain whether the Nautilus figures show mean values of ice draft excluding areas of open water, or whether they give the mean ice draft as we define it to include the whole track. When we consider all factors, we do not believe that our observations suggest that there has been a secular change in the mean thickness of the Arctic Ocean pack ice in the North PoleSpitsbergen region during the $\mathrm{I} 3$ year interval between the two voyages. One likely explanation is that the Nautilus voyage was made at the height of the summer melt season, at which time a large proportion of the previous winter's (first-year) ice would have been dissipated and there would be very little young ice. Since most of the ice would be old ice, average draft must be greater simply because there would be no younger ice to reduce the overall mean. Although in winter old floes must be thicker than they are in summer, the overall winter mean may be reduced to below the summer mean by the large stretches of young ice and first-year ice that are found everywhere during the winter. 
These comparisons highlight the extreme difficulty of comparing different sets of apparently similar sea-ice data. Moreover different investigators have used different definitions and different criteria for describing pack ice. Some of the problems inherent in the need to make arbitrary definitions to facilitate a particular method of reduction are shown by comparing our results with Swithinbank's (1972) treatment of the same data. Table IV compares the percentage of track with $<30 \mathrm{~cm}$ ice given by Swithinbank's manual analysis and our computer analysis. Although the proportions follow the same general trend, the difference is evidently because the computer analysis interpreted the lower culminations of sinusoidal depth-holding oscillations of the submarine as thicker ice whenever they reached or exceeded $30 \mathrm{~cm}$ from the sea-level base line, regardless of whether or not there was any subjective indication of the presence of ice. Since any track must encounter all stages in the progressive

$\begin{array}{ccc}\text { TABle IV. } & \begin{array}{c}\text { Proportion OF TRACK HaVing ICE }<30 \mathrm{~cm} \\ \text { THICK }\end{array} \\ \text { Latitude } & \text { Manual analysis } & \text { Computer analysis } \\ { }^{\circ} \mathrm{N} . & \% & \% \\ 89-90 & \mathrm{I} & 0.5 \\ 88-89 & \mathrm{I} & 1.1 \\ 87-88 & 2 & 1.1 \\ 86-87 & 9 & 5.6 \\ 85-86 & 5 & 3.5\end{array}$

coalescence of independent ridges to become multiple composite ridges, any arbitrary definition of an independent keel must play a large part in the results of an ice-keel count. Swithinbank used the term "ice keel" to mean a keel whose draft was > $>\mathrm{m}$ and was at the same time at least $5 \mathrm{~m}$ more than that of the shallowest troughs on either side of it. In Figure 5 we have shown that this gives rise to a larger number of ice keels and in Table $\mathrm{V}$ we compare the total counts of ice keel resulting from the two methods. Some authors have not defined their terms, with the result that few valid comparisons can be made with other sets of data. We conclude that faster progress could be made if methods and analyses could be standardized through the introduction of a few arbitrary but essential definitions. Standard methods of sounding and deconvolution are also needed because of the problem of resolving high points between ice keels. When such matters are agreed, the type of statistics best suited to the problem may also become clearer.

\begin{tabular}{|c|c|c|}
\hline $\begin{array}{c}\text { Latitude } \\
{ }^{\circ} \mathrm{N} \text {. }\end{array}$ & $\begin{array}{c}\text { Swithinbank } \\
\text { (1972, p. 249) }\end{array}$ & This work \\
\hline $89-90$ & 202 & 177 \\
\hline $\begin{array}{l}88-89 \\
87-80\end{array}$ & 196 & 144 \\
\hline $87-88$ & $\begin{array}{l}312 \\
262\end{array}$ & $\begin{array}{r}170 \\
179\end{array}$ \\
\hline $\begin{array}{l}86-87 \\
85-86\end{array}$ & $\begin{array}{l}262 \\
163\end{array}$ & $\begin{array}{r}84 \\
115\end{array}$ \\
\hline
\end{tabular}

\section{Acknowledgements}

We wish to express our thanks to British Petroleum Company Ltd., who provided finance for the extensive analyses presented in this paper which were carried out by Elizabeth Williams. Support from the Ministry of Defence and the officers and men of H.M.S. Dreadnought is gratefully acknowledged. 


\section{REFERENCES}

Harrison, C. H. 1970. Reconstruction of subglacial relief from radio-echo sounding records. Geophysics, Vol. 35 , No. 6, p. I099-1 I5.

Hibler, W. D., III, and others. 1972. Statistical aspects of sea-ice ridge distribution, [by] W. D. Hibler III, W. F. Weeks and S. J. Mock. Journal of Geophysical Research, Vol. 77, No. 30, p. 5954-70.

Hibler, W. D., III, and others. I 974 . Classification and variation of sea ice ridging in the western Arctic basin, [by] W. D. Hibler III and S. J. Mock, W. B. Tucker III. Journal of Geophysical Research, Vol. 79, No. 18, p. 2735-43.

Lyon, W. K. I961. Ocean and sea-ice research in the Arctic Ocean via submarine. Transactions of the New York Academy of Sciences, Ser. 2, Vol. 23, No. 8, p. 662-74.

Swithinbank, C. W. M. 1972. Arctic pack ice from below. (In Karlsson, T., ed. Sea ice. Proceedings of an international conference. Sponsored by the National Research Council of Iceland. Cosponsored by the Bauer Scientific Trust with financial support from UNESCO. Reykjavik, Iceland, May IO-I3, I97I. Reykjavík, National Research Council, p. 246-54.)

\section{DISCUSSION}

W. D. Hibler III : I suspect that the basic difference between our results and yours is caused by the difference in the ridge definition. It seems likely that the correlation between mean ridge depth and frequency is - as you note in your paper-forced by the correlation of mean ridge depth with volume of deformed ice. By relaxing the Rayleigh criterion somewhat perhaps the ridge counts will correlate with mean ridge depth.

C. W. M. Swithinbank: We take your point. Perhaps a good way to compare the degree of ridging in different areas would be to report the volume of ice below $5 \mathrm{~m}$ draft.

J. F. NyE: You mentioned that the deconvolution of the record by using Harrison's method gave an $8 \%$ reduction in the calculated volume of the ice. That deconvolution is, of course, two-dimensional. Perhaps a three-dimensional deconvolution would give a further reduction of similar magnitude. If this were to be attempted I suggest that it might be easiest not to try to deconvolute the actual record once again, but rather to try to do it statistically. That is to say, assume that the bottom surface is made up of linear keels of the general nature suggested by the traverse and other experience, and then calculate how much difference would be made, on the average, by extending the deconvolution from two to three dimensions.

Swithinbank: This is a good idea and we will experiment with it. 